\title{
Bacterial Transfer to Cups and Water by Drinking
}

\section{Paul Dawson, Hayley Thorson, Kelly Hooton, Justin Runey, David Hughes, Sally Foster, Melissa Roskosky, Sutton Fain-Swartz, Danielle Lynn, Inyee Han}

Food, Nutrition and Packaging Sciences Department, Clemson University, Clemson, SC, USA

Email:pdawson@clemson.edu

How to cite this paper: Dawson, P., Thorson, H., Hooton, K., Runey, J., Hughes, D., Foster, S., Roskosky, M., Fain-Swartz, S., Lynn, D. and Han, I. (2018) Bacterial Transfer to Cups and Water by Drinking. Food and Nutrition Sciences, 9, 1386-1390. https://doi.org/10.4236/fns.2018.912100

Received: November 26, 2018 Accepted: December 25, 2018 Published: December 28, 2018

Copyright $\odot 2018$ by authors and Scientific Research Publishing Inc. This work is licensed under the Creative Commons Attribution International License (CC BY 4.0).

http://creativecommons.org/licenses/by/4.0/

\begin{abstract}
Bacterial transfer is a concern when sharing food and drink, so to address this concern, this study examined the bacterial transfer onto and into plastic drinking cups. Two experiments were performed to: 1) test bacterial transfer to the rim of a plastic drinking cup, and 2) test residual bacteria in the liquid that was consumed from the cup. Bacteria were enumerated from the cup rim and the water in the cup. The results for both types of transfer showed higher bacterial populations on cups exposed to drinking compared to those where no drinking occurred. However, there was more bacterial transfer to the rim of the plastic cup than the liquid inside the cup.
\end{abstract}

\section{Keywords}

Drinking from Cups, Bacterial Transfer

\section{Introduction}

In many social situations including parties, sports events and religious services, a drinking cup or bottle can be shared by multiple individuals. These situations raise questions about the extent of bacterial transfer between individuals using the same cup, as well as possible transfer of disease causing pathogenic bacteria. The New South Wales Football Association posts an Official Meningococcal Association Notice to all ages of soccer players warning of the potentially fatal danger of sharing water bottles or drinking glass due to transfer of Meningcoccal bacteria, which is carried in saliva [1]. The Notice states that about 500 Australians contract the disease annuals and up to 4 million can be carriers. Additional studies where sharing beverages are discussed concern the use of a silver common cup for Church Communion services as early as the 1800s [2]. Communion cups and wince exhibited growth of pathogenic and non-pathogenic bacteria when cultured following the church service [3]. While some trials demonstrated 
only the growth of normal flora, other trials revealed the presence of pathogenic bacteria [4]. On the other hand, in a survey comparing subjects taking communion and those not, no increase in illness due to communion participation was reported [5]. However, this survey did not test if pathogens or disease could be transferred by sharing drink. A review of infections associated with religious rituals cited the afore mentioned study stating that no documented case of transfer of disease by communion however, that transfer of oral bacteria did occur and that people exhibiting respiratory illness or mouth sores should not participate in communion [6]. Sharing drinks in general is believed to possibly transfer bacterial and viral pathogens in saliva that cause diseases such as Strep throat, the common cold, mumps, meningitis [7]. Sharing drinks in social settings is not uncommon with plastic cups often used in these settings and there is a lack of published studies on the transfer of oral bacteria to plastic cups. Therefore, the current study determined the transfer of oral bacteria to plastic cup rims and to water contained in the cup by drinking.

\section{Materials and Methods}

Two separate experiments were conducted to determine; 1) transfer of bacteria to fluid after drinking from a cup and 2) transfer of bacteria to a cup rim after mouth contact with the cup. The study was conducted on a college campus over a 10 week period.

\subsection{Transfer of Oral Bacteria to a Drink}

In order to test the transfer of bacteria from the mouth into a solution within a plastic cup, subjects took three sips of $50 \mathrm{ml}$ of distilled water (paying careful attention as to not drink the entire amount of fluid) from three different locations on the cup. Before adding the distilled water to the plastic cup, both the experimental and control cups were weighed and after the individual had sipped from the plastic cup it was weighed again and recorded. Subjects left an average of 25 $\mathrm{ml}$ of water in the cup after three sips. A $1 \mathrm{~mL}$ sample was taken from each cup, serially diluted then $0.1 \mathrm{ml}$ of the dilutions as well as $0.1 \mathrm{ml}$ directly from the cup were spread plated in duplicate using standard plate count (SPC) agar (Difco laboratories, Detroit, MI, U.S.A) then incubated at $37^{\circ} \mathrm{C} \pm 2{ }^{\circ} \mathrm{C}$ for $48 \mathrm{hrs}$. Dilutions with 25 - 250 colonies were counted and then converted to $\log \mathrm{cfu} / \mathrm{cup}$.

\subsection{Transfer of Oral Bacteria to the Cup}

To test the transfer of bacteria from the mouth to the rim of an empty plastic cup, subjects placed their mouth at three different evenly spaced locations around the rim of the cup as if they were about to drink the contents of the cup Treated cups were placed into sterile bags then $50 \mathrm{~mL}$ of sterile $0.1 \%$ peptone and bacteria were enumerated as described previously described.

\subsection{Statistical Analysis}

Four separate replications of each experiment (bacteria transferred to the fluid 
and bacteria transferred to the cup rim) were conducted with four different subjects and 2 observations were taken for each sample. There were two treatments for each experiment of placing the mouth on the cup/drinking from the cup or a control treatment for each experiment where no mouth contact or drinking was used. A total of 32 observations for each experiment were taken and these were subjected to an analysis of variance (ANOVA) which determined the level of effect of the treatments on bacterial population for each of the 2 experiments (1) transfer of bacteria to fluid after drinking from a cup and 2) transfer of bacteria to a cup rim after mouth contact with the cup). The means for each treatment were compared when treatments were significant $(P \leq 0.05)$ and means separated using the Statistical Analysis System pdiff command.

\section{Results and Discussion}

All cups rims and water in cups that were sipped had bacteria transferred from the mouth. The amount of bacteria present on the rim of the cup is significantly higher than the bacteria present on the rim of the control cup (Figure 1). Additionally, there was a higher population of bacteria in water from cups from which sips had been taken compared to the population from cups not sipped. The number of bacteria transferred to the cup rim was greater than the number transferred to the drinking water. Both controls contained minimal bacteria, proving that there was a significant transfer of bacteria from the mouth to both the rim of the cup and to water contained inside the cup after 3 sips. The average number of bacteria recovered from the rim was in the 100,000 range compared to less than 50 organisms for the cups not contacted by the mouth during drinking. Similarly, the water from cups that had been sipped had over 1000 bacteria compared to less than 10 bacteria per $25 \mathrm{ml}$ of water. Furthermore, the maximum amount of bacteria recovered from the rim and water exposed to sipping was 1 million and 15,500, respectively.

The reason for the large difference of colony forming units from the rim treatment compared to the water treatment could be due to the fact that the rim has more contact with the mouth than the water. The mouth has several genera

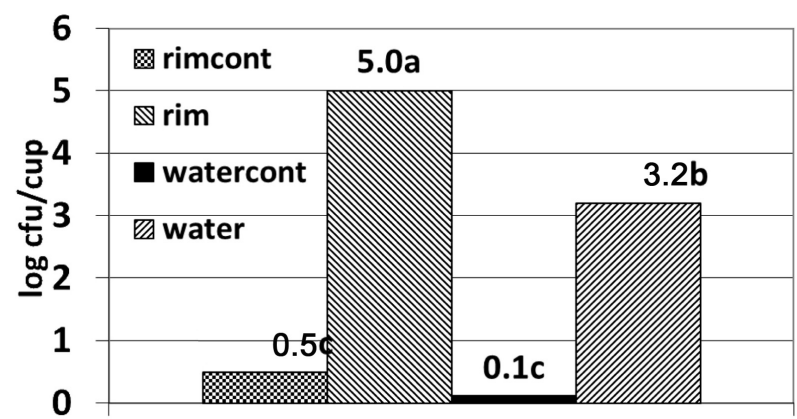

Figure 1. Total aerobic bacteria recovered from the cup (rimcount), the cup after drinking (rim), water (watercount) and water after drinking (watercount). $(\mathrm{N}=32)$. a-c values with different letters are significantly different $(\mathrm{p} \leq 0.05)$. 
of microorganisms that make up the normal flora. Streptococcus, lactobacillus, and fusobacterium are some of the few bacteria normally present. [8] Food particles and cell debris contribute nutrients to create favorable conditions for many species of bacteria. Numerous studies have evaluated the transfer and survival of bacteria on communion cups [9] [10] [11] [12] [13]. Furlow and Dougherty (1993) [5] found that eight of 16 randomly sampled communion cups carried oral pathogens after the communion service. Hobbs et al. (1967) [11] found oral bacteria were left by 6 out of 7 subjects tested depositing from 20 to 2730 organisms on the chalice and from 15 to 320 after wiping with a cloth. Oral bacteria are transferred by direct contact and in saliva through the liberation of bacteria from the mucosa and biofilms within the mouth [14]. In addition to resident oral bacteria, infectious diseases are spread via oral saliva [10] [15].

\section{Conclusions}

Several diseases (including the common cold, influenza, meningitis, rubella, chicken pox, measles, tuberculosis, cold sores and Staph infections) are spread from the mucus or skim of infected individuals [16]. Since sharing of plastic drinking cups can contribute to the transfer of bacteria and other disease agents through both direct contact with the cup and by consumption of fluids containing transferred microbes, this practice should be limited or eliminated to minimize the risk of contracting disease.

Technical Contribution No. 6702 of the Clemson University Experiment Station.

\section{Conflicts of Interest}

The authors declare no conflicts of interest regarding the publication of this paper.

\section{References}

[1] Meningococcal Notice the Danger of Sharing Drink Bottles. http://www.sdsfa.com.au/Library_2002/water\%20bottles.pdf

[2] Anders, H.S. (1897) The Progress of the Individual Cup Movement, Especially among Churches. JAMA, 29, 789-794. https://doi.org/10.1001/jama.1897.02440420023002

[3] Gregory, K.F., Carpenter, J.A. and Bending, G.C. (1967) Infection Hazards of the Common Communion Cup. Canadian Journal of Public Health, 58, 305-310.

[4] Ruby, J. and Goldner, M. (2007) Oral Symbiosis in Oral Disease. Journal of Dental Research, 86, 8-11. https://doi.org/10.1177/154405910708600102

[5] Loving, A.L. (1967) The Effects of Receiving Holy Communion on Health. Journal of Environmental Health, 60, 6-10.

https://www.thefreelibrary.com/The+effects+of+receiving+Holy+Communion+on +health.-a019736122

[6] Pellerin, J. and Edmond, M.B. (2013) Infections Associated with Religious Rituals. International Journal of Infectious Diseases, 17, e945-e948. https://doi.org/10.1016/j.ijid.2013.05.001 
[7] Connelly, T.P. (2013) Sharing Drinks with Others. Can I Actually Catch a Disease? https://www.huffpost.com/entry/sharing-drinks-healthy_b_3241147

[8] Burrows, W. and Hemmons, E.S. (1943) Survival of Bacteria on the Silver Communion Cup. Journal of Infectious Diseases, 73, 180-190.

https://doi.org/10.1093/infdis/73.3.180

[9] Dancewicz, E.P. (1973) What Is the Risk of Infection from Common Communion Cups? Journal of the American Medical Association, 225, 320.

[10] Furlow, T.C. and Dougherty, M.J. (1993) Bacteria on the Communion Cup. Annals of Internal Medicine, 118, 572-573. https://doi.org/10.7326/0003-4819-118-7-199304010-00027

[11] Gill, O.N. (1988) The Hazard of Infection from the Shared Communion Cup. Journal of Infection, 16, 3-23. https://doi.org/10.1016/S0163-4453(88)96029-X

[12] Gregory, K.F., Carpenter, J.A. and Bending, G.C. (1967) Infection Hazards of the Common Communion Cup. Can Journal of Public Health, 58, 305-310.

[13] Hobbs, B.C., Knowlden, J.A. and White, A. (1967) Experiments on the Communion Cup. Journal of Hygiene, 65, 37-48. https://doi.org/10.1017/S0022172400045502

[14] Bowden, G.H.W. and Hamilton, I.R. (1998) Survival of Oral Bacteria. Critical Reviews in Oral Biology and Medicine, 9, 54-85. https://doi.org/10.1177/10454411980090010401

[15] Harrel, S. and Molinari, J. (2004) Aerosols and Splatter in Dentistry: A Brief Review of the Literature and Infection Control Implications. Journal of the American Dental Association, 135, 429-437. https://doi.org/10.14219/jada.archive.2004.0207

[16] Ways Infectious Disease Spreads (n.d.) SA Health, Government of South Australian. https://www.sahealth.sa.gov.au/wps/wcm/connect/public\%20content/sa\%20health\% 20internet/health\%20topics/health\%20conditions $\% 20$ prevention $\% 20$ and $\% 20$ treatm ent/infectious\%20diseases/ways\%20infectious\%20diseases\%20spread 